\title{
ПРОТИВООПУХОЛЕВЫЕ СОЕДИНЕНИЯ РУТЕНИЯ С МИШЕНЬ-ОРИЕНТИРОВАННЫМИ ЛИГАНДАМИ
}

\author{
А.А. Назаров, И.А. Шутков, М.Р. Гончар, А.А. Антонец \\ Химический факультет, МГУ имени М.В. Ломоносова, \\ 119991, Россия, Москва, Ленинские горы, д. 1, стр. 3.
}

DOI: 10.19163/MedChemRussia2021-2021-113

E-mail: alexey.nazarov@me.com

Платиновые комплексы остаются высокоэффективными химиотерапевтическими лекарственными средствами при лечении злокачественных новообразований, однако их ограниченная селективность, приобретённая или первичная резистентность и большое количество побочных эффектов, затрудняют использование этих соединений для широкого ряда опухолей. Координационные и металлоорганические соединения рутения рассматриваются как возможная альтернатива классических платиновых лекарственных средств, но лишенные их основных недостатков.

Нами разрабатывается подход к конструированию противоопухолевых средств двойного действия, заключающийся в комбинации в одной молекуле атомов $R u(I I)$ и $R u(I I)$ и мишень-ориентированных лигандов, которые действуют на клеточные механизмы специфичные для раковых клеток. Новые соединения проявляют высокую активность против раковых клеточных культур в экспериментах in vitro. Выявлены соединения лидеры комплексов в ряду комплексов $R u(I I I)$ и $R u(I I)$.<smiles></smiles>

Работа выполнена при финансовой поддержке гранта РНФ №19-13-00084, РФФИ №19-03-00394 и РФФИ №19-53-26002. 